\title{
STRATEGI KOMUNIKASI PEMASARAN DI SYIRKAH AQIQAH SURABAYA
}

\author{
Ulandhari $^{1}$, Lilik Hamidah ${ }^{2}$
}

${ }^{1,2}$ Universitas Islam Negeri Sunan Ampel Surabaya

11ulandari@gmail.com, ${ }^{2}$ lilik.hamidah@uinsby.ac.id

\section{Article Info}

Received 11 Agustus 2019

Accepted 10 September 2019

Published 5 Oktober 2019

\section{Keyword:}

Strategi, Komunikasi Pemasaran, Syirkah Aqiqah

\section{Abstract}

This article examines the marketing communication strategy at Syirkah Aqiqah Surabaya. The purpose of this research is to identify the marketing communication strategy carried out by syirkah aqiqah in marketing its products. This study uses a qualitative-descriptive approach to understand the phenomena that occur thoroughly and deeply. The results of this study are the marketing communication strategies used by syirkah aqiqah to market and introduce their products including (1) Syirkah Aqiqah using the Word of Mouth, (2) Syirkah Aqiqah making attractive packaging, (3) Syirkah Aqiqah giving discounts and free one bottle of Syuniz. to create sales promotions, and (4) Syirkah Aqiqah uses interactive marketing or online marketing through Instagram and Facebook.

Artikel ini mengkaji strategi komunikasi pemasaran di Syirkah Aqiqah Surabaya. Tujuan penelitian ini adalah mengidentifikasi strategi komunikasi pemasaran yang dilakukan oleh syirkah aqiqah dalam pemasaran produknya. Penelitian ini menggunakan pendekatan kualitatif-deskriptif untuk memahami fenomena-fenomena yang terjadi secara menyeluruh dan mendalam. Hasil penelitian ini adalah strategi komunikasi pemasaran yang digunakan oleh syirkah aqiqah untuk memasarkan dan mengenalkan produknya meliputi (1) Syirkah Aqiqah menggunakan Word of Mouth, (2) Syirkah Aqiqah membuat packaging yang menarik, (3) Syirkah Aqiqah memberikan diskon dan gratis satu botol Syuniz untuk membuat promosi penjualan, dan (4) Syirkah Aqiqah menggunakan pemasaran interaktif atau pemasaran online melalui media Instagram dan Facebook. 


\section{Pendahuluan}

Perkembangan bisnis yang sangat pesat, menimbulkan persaingan pasar yang cukup ketat. Setiap harinya muncul pelaku bisnis yang mengenalkan produk dengan kreativitas dan inovasi baru sehingga persaingan pasar pun tidak bisa dihindari. Ketika ada sebuah perusahaan yang memulai hal baru tentunya pasti ada perusahaan-perusahaan lain yang akan menciptakan hal yang serupa di mana akan muncul kompetitor kompetitor di bidang yang sama atau bahkan mereka akan melakukan inovasi-inovasi yang lebih baik daripada yang telah dilakukan oleh instansi pertama yang meluncurkan sebuah program. Kreatif dalam menjalankan bisnis menjadi salah satu kunci sukses sebuah perusahaan untuk menciptakan produk yang siap bersaing di pasaran.

Para pelaku usaha dituntut berusaha kreatif dan inovatif, jika tidak usahanya akan tersingkir dari persaingan pasar.Komunikasi pemasaran terpadu adalah meningkatkan angka penjualan, perusahaan gencar melakukan promosi baik melalui periklanan maupun alat-alat komunikasi pemasaran lainnya sepert humas, pemasaran langsung, penjualan personal, dan promosi penjualan, dalam memasarkan produknya. ${ }^{1}$ Untuk itu, dibutuhkan pendekatan baru dimana alatalat komunikasi pemasaran bisa berjalan efektif dan terintregasi, Salah satunya dngan cara melakukan komunikasi pemasaran terpadu.Proses komunikasi pemasaran ini akan terjadi ketika komunikator menyampaikan pesan-pesan yang telah dibuat sebelumnya melalui iklan yang mereka pasang pada media-media yang telah ditentukan.

Pemasaran disini adalah sebuah kegiatan yang biasanya dilakukan oleh perusahaan untuk menghadapi persaingan atau mempertahankan kelangsungan dari usaha yang mereka jalankan untuk memperoleh laba sesuai keinginan perusahaan tentunya mereka harus berjuang lebih karena tentunya komunitas kompetitor yang ada di dunia luar pasti akan sangat banyak.

Di dalam dunia bisnis strategi pemasaran memiliki peran yang sangat penting dalam tahap pembentukan kesadaran dan pemahaman konsumen. Dengan demikian sebuah perusahaan membutuhkan perencanaan strategi yang tepat agar dapat diterima dengan mudah oleh masyarakat. Strategi yang dilakukan oleh perusahaan pun beraneka ragam, seperti menawarkan suatu produk dengan kemasan yang menarik, dan harga terjangkau. Dalam konsep ini perusahaan harus bisa mengkoordinasikan alat-alat komunikasi pemasaran agar bisa bekerja bersama-sama. Saling mendukung satu sama lain sehingga bisa saling melengkapi dalam mencapai target audiens yang diinginkan.

Sementara menurut Sistaningrum, promosi adalah suatu upaya aatau kegiatan perusahaan dalam mempengaruhi "konsumen aktual maupun "konsumen potensial" agar mereka mau melakukan pembelian terhadap produk yang 
ditawarkan, saat ini atau dimasa yang akan datang. ${ }^{2}$

Konsumen aktual adalah konsumen yang langsung membeli produk yang ditawarkan pada saat atau sesaat setelah promosi produk tersebut dilancarkan perusahaan. Dan konsumen potensial adalah konsumen yang berminat melakukan pembelian terhadap produk yang ditawarkan perusahaan di masa yang akan datang. Promosi penjualan adalah merupakan kegiatan perusahaan untuk menjajakan produk yang dipasarkan sedemikian rupa sehingga konsumen akan mudah melihatnya dan bahkan dengan cara penempatan dan pengaturan tertentu maka produk tersebut akan menarik perhatian konsumen.

Di dalam dunia bisnis berbagai bidang usaha sangatlah banyak, salah satunya adalah usaha menawarkan jasa.Salah unit usaha yang menerima jasa adalah Syirkah Aqiqah.

Syirkah Aqiqah merupakan pengusaha yang bergerak dibidang jasa pelayanan aqiqah, yang berdiri pada tahun 2006 yang didirikan oleh Imam Winarko selaku owner yang bertempat dijalan sidosermo VI gang III no 29, dan mempunyai cabang di gresik. Syirkah Aqiqah mampu menjual setiap bulannya 20 ekor kambing.Berdasarkan fenomena yang dijumpai dalam dunia bisnis syirkah Aqiqah mampu meningkatkan penjualan.Setalah 2006, bulanjanuari, februari pendapatan Syirkah Aqiqah pertama kali meningkat, setelah itu

\footnotetext{
${ }^{2}$ Sistaningrum, Manajemen Promosi Pemasaran. (Jakarta: PT Index, 2002), 98.
}

pendapatan mengalami peningkatan dan penurunan sampai tahun 2009 sampai tahun 2012 sampai 200 ekor perbulan. Syirkah Aqiqah memasarkan produknyan melalui, Radio suara islam, majalah muslim, dan media sosial seperti internet, instagram, dan facebook.

Dari penjelasan singkat diatas tergambar bahwa Syirkah Aqiqah adalah sebuah perusahaan yang menarik untuk diteliti. Perkembangan penjualan yang terjadi di Syirkah Aqiqah membuat peneliti ingin mengetahui strategi yang digunakan. Oleh sebab itu, peneliti mengangkatnya dengan skripsi yang berjudul "Strategi Komunikasi Pemasaran Syirkah Aqiqah Di Surabaya".

\section{Kajian Pustaka}

\section{Strategi Pemasaran}

Strategi pemasaran adalah logika pemasaran, dan berdasarkan itu, unit bisnis diharapkan untuk mencapai sasaran-sasaran pemasarannya. Strategi pemasaran terdiri dari pengambilan keputusan tentang biaya pemasaran dari perusahaan, bauran pemasaran, dan alokasi pemasaran dalam hubungannya dengan keadaan lingkungan yang di harapkan dan kondisi persaingan. ${ }^{3}$

Menurut Swastha Strategi adalah serangkaian rancangan besar yang menggambarkan bagaimana sebuah perusahaan harus beroperasi untuk mencapai tujuannya.Menurut W.Y. Stanton pemasaran adalah sesuatu yang

3 Philip Kotler, Edisi Kelima Manajemen Pemasaran, Analisis, Perencanaan Dan Pengendalian jilid 1, (Jakarta: Erlangga, 1994), 98. 
meliputi seluruh system yangberhubungan dengan tujuan untuk merencanakan dan menentukanharga sampai dengan mempromosikan dan mendistribusikan barangdan jasa yang bisa memuaskan kebutuhan pembeli actual maupun potensial. ${ }^{4}$

Menurut Bennett, strategi pemasaran merupakan pernyataan (baik secara implisit maupun eksplisit mengenai bagaimana suatu merek atau lini produk mencapai tujuannya, sementara menurut Tull dan Kahle merupakan alat fundamental yang direncanakan untuk mencapai tujuan perusahaan dengan menggembangkan keunggulan bersaing yang berkesinambungan melalui pasar yang dimasuki dan program pemasaran yang digunakan untuk melayani pasar sasaran tersebut. Pada dasarnya strategi pemasaran memberikan arah dalam kaitanya dengan variabel variabel seperti segmentasi pasar, identifikasi pasar sasaran, positioning, elemen bauran pemasaran, dan biaya bauran pemasaran.Strategi pemasran merupakan bagian intergral dari strategi bisnis yang memberikan arah pada semua fungsi manajemen dan suatu organisasi. ${ }^{5}$

Hubungan strategi dan pemasaran menjadi penting dalam dunia bisnis, karena pada hakikatnya hubungan ini merupakan langkah langkah kreatif yang berkesinambungan yang diupayakan oleh sebuah perusahaan guna mencapai target pemasaran

4 Agus Hermawan, Komunikasi Pemasaran, (Jakarta: Penerbit Erlangga, 2012), 33. terbaik dalam rangka mewujudkan kepuasan konsumen secara maksimal. Strategi pemasaran sangat diperlukan untuk mencegah penurunan jumlah konsumen serta jatuhnya daya saing produk bisnis di pasar. Strategi pemasaran yang menyatu merupakan rangkaian proses pemasaran secara lebih maksimal, Tanpa adanya strategi pemasaran yang teruji, bisa dipastikan pemasaran akan jatuh, Melalui strategi ini sebuah proses pemasaran yang baik dapat dipertahankan, memberikan cara-cara yang baru yang membuat para pelanggan senantiasa menemukan keunikan dalam produk, hal ini merupakan salah satu strategi yang dibutuhkan dalam pemasaran.

Proses pemeasaran dimulai dari menemukan apa yang diinginkan oleh konsumen. Sehingga akhirnya pemasaran memiliki tujuan yaitu konsumen potensial mengetahui secara detail produk yang kita hasilkan dan perusahaan dapat menyediakan semua permintaan mereka atas produk yang dihasilkan.

Lalu perusahaan juga dapat menjelaskan secara detail semua kegiatan yang berhubungan dengan pemasaran. Kegiatan pemasaran ini meliputi berbagai kegiatan, mulai dari penjelasan mengenai produk, desain produk, promosi produk, mengiklankan produk, komunikasi kepada konsumen, sampai pengiriman produk agar sampai ke tangan konsumen secara cepat.

5 Fandy Tjiptono, Strategi Pemasaran edisi III, (Yogyakarta: Andi, 2008), 6. 


\section{Strategi Komunikasi}

Komunikasi pada hakikatnya adalah suatu proses sosial, yaitu sesuatu yang berlangsung atau berjalan antara manusia. Istilah proses memang berarti sesuatu yang sedang berlangsung. Artinnya proses merupakan perubahan atau serangkaian tindakan atau peristiwa selama beberapa waktu menuju suatu hasil tertentu. Jadi setiap langkah, mulai pesan diciptakan sampai menimbulkan pengaruh atau perubahan pada sasaran, adalah proses komunikasi yang azasi.

Sebagai proses sosial, maka dalam komunikasi, selain terjadi hubungan antara manusia juga terjadi interaksi atau saling mempengaruhi. Justru itu semua pihak yang terlibat dalam proses komunikasi, mau tidak mau pasti mengalami perubahan. Itulah sebabnya perubahan merupakan hasil proses komunikasi yang tidak mungkin dielakkan.

Istilah komunikasi diambil dari perkataan inggris "communication". Istilah ini bersumber dari bahasa latin "communication" yang artinya pemberitahuan, pemberian bahagia, pertukaran, dimana sipembicara mengharapkan pertimbangan atau jawaban dari pendengarnya. Kata sifatnnya "communis" artinya bersifat umum dan terbuka, bersamasama.Kata kerjanya "communicare" artinya bermusyawarah, berunding atau berdialog. ${ }^{6}$
Jadi komunikasi atau berkomunikasi berarti suatu upaya bersama-sama orang lain, atau membangun kebersamaan dengan orang lain dengan membentuk perubahan. Komunikasi sebagai proses saling membagi atau menggunakan informassi secara bersama antara pesera dalam proses informasi.

\section{Strategi Komunikasi Pemasaran}

Peran komunikasi pemasaran adalah untuk mengontribusikan brand equity dengan mendirikan merek dalam hubungan yang kuat, baik, dan juga adanya kesatuan yang unik. Para pemasar juga dituntut untuk mengevaluasi kemungkinan pilihan komunikasi yang ada untuk membuat struktur penggetahuan tentang merek agar berjalan efektif. Apalagi terdapat perbedaan kekuatan bauran komunikasi yang digunankan maka hasilnaya juga akan berbeda. Komunikasi merupakan suatu kegiatan atau aktivitas yang dilakukan setiap hari dengan masyarakat atau lingkungannya. Dan bahkan komunikasi telah menjadi suatu fenomena bagi terbentuknya suatu masyarakat atau komunitas yang terintegrasi oleh informasi, dimana masing-masing individu dalam masyarakat itu sendiri saling berbagi

\footnotetext{
${ }^{6}$ Fandy Tjiptono, Strategi, 12.
} 
informasi (information sharing) untuk mencapai tujuan bersama. ${ }^{7}$

Komunikasi berfungsi sebagai instrument untuk dapat mencapai tujuan, baik tujuan pribadi maupun pekerjaan, baik tujuan jangka pendek maupun tujuan jangka panjang. Tujuan jangka pendek misalnya adalah memperoleh pujian atas kesan yang baik dari orang lain serta mendapatkan keuntungan material, ekonomi, dan politik yang didapat melalui pengelolaan kesan verbal maupun nonverbal. Sedangkan tujuan jangan panjang adalah untuk mencapai kesuksesan dalam karier yang dapat diraih lewat keahlian berkomunikasi. ${ }^{8}$ Komunikasi berperan penting di hampir semua bidang yang ada termasuk dalam bisnis maupun pemasaran. Komunikasi dapat berguna untuk mendukung adanya proses pemasaran dari produk maupun jasa. Pemasaran sendiri merupakan sebuah strategi dalam menentukan keberhasilan berbisnis, karena pemasaran tidak hanya sebagai kegiatan penjualan, melainkan juga harus dipahami dalam pandangan baru yaitu kebutuhan dari pelanggan. ${ }^{9}$

Pengelola pemasaran hingga kini masih ada yang beranggapan bahwa kegiatan promosi yang paling efektif adalah beriklan melalui media massa. Anggapan ini menyebabkan fungsi

7 Syaiful Rohim, Teori Komunikasi: Perspektif, Ragam dan Aplikasi (Jakarta: Rineka Cipta,2009), 8.

8 Deddy Mulyana, Ilmu Komunikasi Suatu Pengantar, (Bandung: Remaja Rosdakarya, 2010), 34. promosi suatu perusahaan, selama beberapa dekade terakhir, umumnnya didominasi oleh iklan media massa. Perusahaan bergantung pada biro iklan dalam memberikan bimbingan dan saran kepada manajemen mengenai hampir segala hal yang terkait dengan komunikasi pemasaran. Bentuk bentuk komunikasi pemasaran lain, selain beriklan di media massa, seperti promosi penjualan atau pemasaran langsung masih dianggap sebagai pekerjaan tambahan dan lebih sering digunakan pada kasus kasus tertentu saja. Konsultan humas hanya digunakan untuk mengelola kegiatan pubilsitas, mengelola citra serta menangani urusan dengan publik. Humas belum dipandang sebagai peserta yang integral dalam kegiatan promosi perusahaan. ${ }^{10}$

Pada 1980 an berbagai perusahaan di Negara-negara maju, khususnya Amerika serikat, mulai menyadari perlunya upaya untuk mengintegrasikan seluruh instrumen promosi yang dimiliki untuk meningkatkan penjualan. Perusahaan perusahaan mulai bergerak menuju proses yang disebut dengan komunikasi pemasaran terpadu atau integrated marketing communication (IMC), yang mencakup upaya koordinasi dari berbagai elemen promosi dan kegiatan pemasaran

\footnotetext{
${ }^{9}$ Philip Kotler dan Gary Amstrong, Prinsipprinsip Pemasaran, (Jakarta: Erlangga, 1999), 3.

10 Morissan, Periklanan Komunikasi Pemasaran Terpadu, (Jakarta: Kencana Prenamedia Group, 2010), 6.
} 
lainnya. Ketika penanggung jawab pemasaran di berbagai perusahaan mulai menerapkan konsep komunikasi pemasaran terpadu, mereka juga meminta biro iklan untuk mengoordinasikan berbagai instrumen promosi yang tersedia dan tidak hanya mengandalkan pada iklan di media massa.

Perusahaan juga mulai melihat hal hal yang diluar perusahaan atau biro iklan dan mulai memanfaatkan para ahli promosi (promotional specialists di berbagai bidang untukmembantu perusahaan mengembangkan dan melaksanakan berbagai komponen dari rencana promosi mereka. ${ }^{11}$

Komunikasi pemasaran terpadu merupakan upaya untuk menjadikan seluruh kegiatan pemasaran dan promosi perusahaan dapat menghasilkan citra atau image yang bersifat satu dan konsisten bagi konsumen. Upaya ini menuntut agar setiap pesan yang keluar harus berasal dari sumber yang sama sehingga segala informasi yang diumumkan perusahaan memiliki kesamaan tema serta positioning yang sama di mata konsumen. Banyak perusahaan di Negara maju saat ini telah menrerapkan IMC (integrated marketing communication) dengan perspektif yang lebih luas. Para pengelola perusahaan melihat imc sebagai cara untuk mengkoordinasikan dan mengelola program komunikasi pemasaran mereka untuk memastikan bahwa mereka memberikan pelanggan

\footnotetext{
${ }^{11}$ Morissan, Periklanan Komunikasi, 7.
}

suatu pesan yang konsisten mengenai perusahaan dan/atau merek yang dimiliki. Bagi banyak perusahaan, imc memberikan banyak perbaikan dibandingkan metode tradisional yang memperlakukan berbagai elemen komunikasi pemasaran sebgai kegiatan terpisah. $^{12}$

Dengan semakin pahamnya pengelola pemasaran terhadap IMC (integrated marketing communication), mereka mengakui bahwa IMC (integrated marketing communication) ternyata menawarkan lebih dari sekedar gagasan untuk mengoordinasikan seluruh elemen program pemasaran dan komunikasi. Pendekatan imc juga dapat membantu perusahaan mengidentifikasi metode yang paling tepat dan efektif untuk berkomunikasi dan membangun hubungan dengan pelanggan dan juga pihak pihak terkait lainnya, seperti karyawan, pemasok, investor, kelomok kepentingan, dan masyarakat umum.

Komunikasi pemasaran dapat di pahami dengan menguraikan dua unsur pokoknya, yaitu komunikasi dan pemasaran. Komunikasi adalah proses dimana pemikiran dan pemahaman disampaikan antarindividu, atau antara organisasi dengan individu. Pemasran adalah sekumpulan kegiatan di mana perusahaan dan organisasi lainnya mentranfer nilai nilai (pertukaran antara mereka dengan pelanggannya. Tentu saja pemasaran lebih umum pengertiannya dari pada komunikasi pemasaran namun kegiatan pemasaran

\footnotetext{
${ }^{12}$ Morissan, Periklanan Komunikasi, 9.
} 
banyak melibatkan aktivitas
komunikasi. Jika digabungkan,
komunikasi
mempresentasikan gabungan semua
unsur dalam bauran pemasaran, yang
memfasilitasi terjadinya pertukaran
dengan menciptakan suatu arti yang
disebarluaskan kepada pelanggan atau
kliennya ${ }^{13}$
Dalam sebuah organisasi atau perusahaan komunikasi pemasaran memiliki peranan memberikan informasi, membujuk, mengingatkan konsumen secara langsung maupun tidak tentang produk dan merek yang akan dijual. Komunikasi pemasaran melakukan banyak fungsi kepada konsumen atau pasar sasaran terutama memberitahu dan memperlihatkan seputar bagaimana dan mengapa produk itu digunakan, siapa pasar sasarannya dimana dan kapan produk itu dapat diperoleh.

Kerangka dasar komunikasi pemasaran oleh perusahaan dapat diarahkan untuk mempengaruhi konsumen terhadap gaya, dan harga produk, bentuk dan warna kemasan, dekorasi toko, sebagai bentuk komunikasi kepada pembeli. Kotler \& Keller menggambarkan unsur dalam kerangka dasar komunikasi umum sebagai alat komunikasi antara pemasaran dengan pembeli. ${ }^{14}$

Kegiatan komunikasi pemasaran juga memiliki peran yang sangat

13 Terence A. Shimp, Periklanan Promosi Aspek Tambahan Komunikasi Terpadu Jilid 1 Edisis Kelima, (Jakarta: Erlangga, 2003), 4. penting dalam membentuk ekuitas merek dan mendorong efektivitas dan efisiensi penjualan suatu produk.Misalnya dengan menciptakan kesadaran tentang merek, menciptakan penilaian atau perasaan tentang merek yang positif, dan dapat memfasilitasikeneksi merek konsumen yang lebih kuat.Menurut Philip Kotler \& Kevin Lane Keller membangun merek melalui komunikasi pemasaran terintegrasi. ${ }^{15}$

\section{IMC (Integrated Marketing Communication)}

IMC (Integrated Marketing Communication) adalah proses pengembangan dan implementasi berbagai bentuk program komunikassi persuasif kepada pelanggan dan calon pelanggan secara berkelanjutan. Tujuan imc adalah untuk mempengaruhi atau memberikan efek langsung kepada perilaku khalayak sasaran yang dimilikinya. Imc menganggap seluruh sumber smber yang dapat menghubungkan pelanggan atau calon pelanggan dengan produk atau jasa dari suatu merek atau perusahaan, adalah jalur yang potensial untuk menyampaikan pesan dimasa datang. Lebih jauh lagi, imc menggunkan semua bentuk komunikasi yang relevan serta yang dapat diterima oleh pelanggan dan calon pelanggan. Dengan kata lain,

14 Hermawan Kertajaya, Positioning Diferensi, (Jakarta: PT. Gramedia Pustaka Utama, 2005), 32.

${ }^{15}$ Frank Jefkins, Public Relation Untuk Bisnis, (Jakarta: PT. Pustaka Binaman Presindo, 1987), 95. 
proses imc berawal dari pelanggan dan calon pelanggan, kemudian berbalik kepada perusahaan untuk menentukan dan mendefinisikan bentuk dan metode yang perlu dikembangkan bagi program komunikasi yang persuasif. ${ }^{16}$

Perkembangan IMC (Integrated Marketing Communication) yang paling signifikan bagi dunia pemasaran terjadi pda tahun 1990-an dengan munculnya gerakan di banyak perusahaan untuk menerapkan komunikai pemasaran terpadu. Perusahaan melakukan perubahaan strategi pemasaran dari pemasaran tradisional beralih kepada imc yan harus berlanjut hingga saat ini.Berbagai perusahaan besar maupun kecil di Negara maju saat ini sudah menggunakan pendekatan komunikasi pemasaran terpadu dalam menetukan perencanaan dan strategi komunikasi pemasaran mereka.Gerakan ini pun sudah di ikuti oleh sebagian perusahaan besar di Negara berkembang termasuk Indonesia. ${ }^{17}$

Terdapat sejumlah alassan mengapa perusahaan memilih untuk menggunakan pendekataan imc ini dalam mengelola pemasaran mereka.Alasan fundamental adalah munculnya pemahaman mengenai pentingnya upaya untuk memadukan berbagai fungsi komunikasi yang tersedia dari pada memberikan

16 Terence A. Shimp, Periklanan Promosi Aspek Tambahan Komunikasi Terpadu Jilid 1 Edisis Kelima, (Jakarta: Erlangga, 2003), 24.

17 Morissan, Periklanan Komunikasi Pemasaran Terpadu, (Jakarta: Kencana Prenamedia Group, 2010), 12. berbagai fungsi komunikasi itu bekerja sendiri-sendiri.Dengan

mengoordinasikan segala upaya komunikasi pemasaran yang dilakukan masing-masing bagian, maka perusahaan dapat menghindari terjadinya duplikasi pekerjaan.Perusahaan memperoleh manfaat dari sinergi di antara berbagai instrumen promosi serta mengembangkan program komunkasi pemasaran yang lebih efektif dan efisien. ${ }^{18}$

\section{Metode Penelitian}

Dalam penelitian ini peneliti menggunakan pendekatan deskriptif kualitatif. Deskriptif kualitatif mengulas masalah-masalah yang ada dan berusaha menelaah fenomena sosial, melalui penelitian deskriptif kualitatif peneliti merasa akan lebih mudah menjabarkan hasil dari data data dan fakta yang telah didapati di lapangan selama penelitian berlangsung, sebagaimana yang dikemukakan oleh Lexy J. Maleong bahwa penelitian kualitatif adalah sebagai prosedur yang menghasilkan satu deskriptif berupa kata-kata tertulis atau lisan dari orang-orang dan perilaku yang diamati. ${ }^{19}$

\footnotetext{
${ }^{18}$ Morissan, Periklanan Komunikasi, 12.

19 Lexy. J. Maleong, Metodologi Penelitian Kualitatif, (Bandung: Rosda Karya, 2005), 4.
} 


\section{Hasil dan Pembahasan}

Peneliti lakukan berikut adalah hasil deskripsi dan penyajian data yang telah peneliti peroleh sebagai berikut. Kegiatan pemasaran Syirkah Aqiqah ini nyatanya tidak lepas dari konsep konsep bauran dalam marketing mix yaitu;

\section{a. Proses Pemasaran Produk di Syirkah Aqiqah Surabaya}

Produk adalah segala sesuatu yang dapat ditawarkan kepada pasar untuk mendapatkan perhatian, dimiliki, digunakan atau dikonsumsi, yang meliputi barang secara fisik, jasa, kepribadian, lokasi, organisasi dan gagasan atau buah fikiran.

Perencanaan yang pertama Syirkah Aqiqah yaitu menentukan produk yang berkualitas. Dengan konsep utama yaitu menawarkan daging yang masih mentah atau yang sudah di masak. Menu-menu masakan di Syirkah Aqiqah juga banyak variannya, tidak hanya menawarkan aneka menu tetapi juag menawarkan paket nasi kotak.

Dalam sebuah produk bukan hanya mengenai barang yang ditawarkan melainkan ada atribut produk yang merupakan unsur-unsur yang memberikan nilai tambah dan juga dapat menjadi salah satu daya tarik bagi konsumen. Atribut tersebut meliputi:

a. Merek.

Merek merupakan nama atau simbol yang bersifat membedakan. Mereknya adalah Syirkah Aqiqah merek dengan taglinenya yang melekat yaitu mudah amanah syar'i "enaknnya kemana-mana" dimana taglinenya itu juga titulis di packaging Syirkah Aqiqah.

b. Kemasan

Berbagai strategi dirancang dengan menyediakan kemasan yang bisa dibawa berbagai level ekonomis mulai dari kemasan ukuran box $(15 \times 22 \mathrm{~cm})$ dan $(25 \times 22 \mathrm{~cm})$.

c. Layanan.

Strategi yang diterapkan Syirkah yang utama yaitu keramahan, supaya konsumen merasa nyaman. Syirkah Aqiqah menyediakan tester untuk konsumen yang ragu akan mengenai rasa tester bisa dikirim ketempatnya langsung.

Syirkah Aqiqah juga mempunyai tatanan kerja yaitu sebelum hari $\mathrm{H}$ pengiriman ada konfirmasi pengiriman terlebih dahulu, setelah barang di kirim lalu besoknnya ada lagi konfirmasi mengenai rasa, dan kepuasan pelanggang.

1) Price (harga)

Syirkah Aqiqah memberikan harga yang disesuaikan dengan target sasarannya. Harga yang diberikan beraneka ragam sesuai dengan jenis massakan yang ditawarkan. Di dalam menarik konsumen Syirkah Aqiqah memberikan promo setiap pemesanan aqiqah bayi usia 714 hari mendapatkan 1 botol SYUNIZ.

2) Promotion (promosi)

Promosi adalah aspek yang penting dalam perihal 
pemasaran berkaitan adanya iklan yang berfungsi sebagai penyebar informasi kepada khalayak. Dalam promosi juga terdapat beberapa strategi yang harus dilakukan sperti halnya yang dilakukan pihak Syirkah Aqiqah dalam meningkatkan jumlah konsumen. Kegiatan Syirkah Aqiqah dalam mempromosikan produknya yaitu denganmemberitahukan informasi atau menawarkan produk melalui media iklan seperti banner, brosur.

Promosi ini dilakukan juga pada pemasaran langsung dengan memanfaatkan media elektronik seperti penggunaan jaringan internet, situs pertemanan seperti facebook, twitter, instagram, hal ini disesuaikan dengan kemajuan teknologi seperti internet yang tengah mewabah khususnya di kalangan masyarakat Kota Surabaya. Selain itu, promosi Syirkah Aqiqah juga mengandalkan penjualan yang dilakukan atas kerjasamadengan radio muslim.

\section{Strategi Komunikasi Pemasaran di Syirkah Aqiqah Surabaya}

Strategi Komunikasi pemasaran pasti digunakan oleh para pelaku usaha untuk memperkenalkan produknya kepada calon konsumen atau khalayak. Dalam komunikasi pemasaran terdapat strategi untuk menjalankan komunikasi pemasaran yang tepat sasaran karena itu komunikasi pemasaran tidak akan berjalan dengan baik jika tidak adanya strategi yang dilakukan.

Dalam komunikasi pemasaran terdapat strategi-strategi untuk menjalankan komunikasi pemasaran yang tepat sasaran, karena itu komunikasi pemasaran tidak akan berjalan dengan baik jika tidak adanya strategi yang dilakukan. Syirkah Aqiqah melakukan kegiatan-kegiatan yang menunjang komunikasi pemasaran untuk mengenalkan produknya kepada calon konsumen.

Strategi komunikasi pemasaran yang lebih tepatnya menggunakan bauran komunikasi pemasaran terdiri dari beberapa elemen yaitu adalah iklan (advertising), promosi penjualan (sales promotion), penjualan personal (personal selling), pemasaran langsung (direct marketing), hubungan masyarakat (public relation) pemasaran interaktif (online marketing).

Syirkah Aqiqah hampir menggunakan seluruh elemen bauran komunikasi pemasaran namun tidak semuannya digunakan. Ada beberapa elemen yang tidak digunakan untuk memasarkan produknya. Dari data yang diperoleh oleh peneliti, online marketing adalah elemen yang paling dominan dipakai oleh Syirkah Aqiqah karena dirasa sangat efektif, memberikan dampak bagi penjualan, dan sangat praktis.

Dengan menggunakan dan melaksanakan bauran komunikasi 
pemasaran secara baik, maka akan berdamapak pada berkembangnya usaha tersebut. Awal mula membuat penjualan personal untuk memberikan kemudahan, keunggulan dan fasilitas, misalnya takut dengan rasanya yang tidak enak Syirkah Aqiqah menyediakan tester, tester bisa di kirim langsung ketempat calon konsumen tanpa repot repot konsumen datang ketempat Syirkah Aqiqah.

Kemudian selanjutnya membuat sebuah sosial media untuk media mempromosikan produk Syirkah Aqiqah karena saat itu sosial media sangat digemari oleh khalayak. Sosial media yang digunakan adalah internet, yang melalui web, facebook, instagram, karena melihat posting-an tersebut dapat menarik minat khalayak, tidak hanya melalui internet tetapi juga melalui media cetak dan media elektronik, media cetaknya melalui majalah Al Akhbar dan Lazismu, sedangkan media elektroniknnya mengunakan radio melalui saluran Suara Muslim. Langkah untuk sukses strategi komunikasi pemasaran di Syirkah Aqiqah Surabaya adalah sebagai berikut:

\section{Syirkah Aqiqah menggunakan strategi Word Of Mouth (WOM)}

Word of mouth atau komunikasi dari mulut kemulut merupakan proses komunikasi yang berupa pemberian rekomendasi baik secara individu maupun kelompok terhadap suatu produk atau jasa yang bertujuan untuk memberikan informasi secara personal, word of mouth dapat berupa komentar atau rekomendasi yang disebarkan pelanggan berdasarkan pengalaman yang diterimanya, memiliki pengaruh yang kuat terhadap pengambilan keputusan yang dilakukan pihak lain. Word of mouth menjadi refrensi yang membentuk harapan pelanggan, word of mouth menjadi salah satu strategi yang sangat berpengaruh di dalam keputusan konsumen dalam menggunakan produk atau jasa.

Word of mouth pencarian informasi dilakukan untuk memperoleh produk yang berkualitas yang dapat memenuhi kebutuhan dan keinginannya. Konsumen akan mencari informasi tersebut ke sumber sumber yang dapat memberikan informasi yang di butuhkan. Rekomendasi dari orang lain berpengaruh sangat besar, apabila rekomendasi itu berasal dari orang yang dikenal, word of mouth sangat kuat karena memberikan manfaat kepada yang bertannya dengan pengalaman langsung tentang produk melalui pengalaman teman atau kerabat. Seperti Syirkah Aqiqah ada konsumen pertama dia mencoba rasa, akhirnnya konsumen tadi menceritakan teman temannya sampai seperti menjadi reseller karena pemesanan melalui dia, meskipun pemesanan di lakukan secara mendadak tapi syirkah aqiqah selalu menerima soalnnya karena si pelanggan tadi sudah cocok, dan 
masih masih banyak lagi pelanggan pelanggan yang menjadi pelantara.

\section{Packaging}

Kemasan produk dapat menjadi hal yang penting dalam strategi komunikasi pemasaran. Kemasan yang menarik dapat mempengaruhi keputusan konsumen dalam membeli produk. Komunikasi ini bisa dalam bentuk desain, warna serta bentuk dari kemasan produk tersebut.

Syirkah Aqiqah dulu pertama kali menggunakan packaging hanya kotak putih polos biasa, mulai berubah karena kenal orang brand mulai tahun 2014 dan dengan berkembangnya jaman sekarang Syirkah Aqiqah mengeluarkan packaging baru yang lebih menarik.

\section{Syirkah Aqiqah memberikan} diskon dan gratis satu botol Syuniz untuk menarik pelanggan yang merupakan bagian dari promosi penjualan

Dari hasil wawancara yang dilakukan oleh peneliti dapat di simpulkan bahwa Syirkah Aqiqah melakukan seles promotion (promosi penjualan) untuk memikat para konsumen dan calon konsumen dan menjadi konsumen tetap. Strateginya yaitu Syirkah Aqiqah memberikan potongan harga setiap pembelian empat sampai lima kali pemesanan, dan geratis satu botol Syuniz untuk pemesanan aqiqah bayi usia 7-14 hari, merupakan promosi penjualan untuk menarik minat konsumen.

Sarana promosi yaitu memberikan potongan harga setiap konsumen yang pernah memesan empat sampai lima kali pemesanan serta mendapatkan gratis satu botol Syuniz untuk pemesanan aqiqah bayi 7 sampai 14 hari. Dari deskripsi data mengenai komunikasi pemasaran yang dilakukan oleh Syirkah Aqiqah, berikut adalah temuan-temuan yang peneliti dapatkan dalam melakukan penelitian saat di lapangan. Seluruh pelaksanaan strategi komunikasi pemasaran yang dilaksanakan oleh Syirkah Aqiqah berjalan sesuai apa yang diharapkan. Peneliti memaparkan hasil penelitian sebagai berikut:

\section{Pemasaran interaktif atau} pemasaran online merupakan strategi terbaik bagi Syirkah Aqiqah

Media sosial memang sedang banyak diminati oleh berbagai kalangan. Ini membuka kesempatan bagi Syirkah Aqiqah untuk mempromosikan produknya melalui sosial media. Media online merupakan salah satu dari elemen bauran komunikasi pemasaran yang saat ini sedang banyak digunakan oleh para pelaku usaha. Disini Syirkah Aqiqah menggunakan Instagram dan Facebook dimana didalamnya terdapat berbagai postingan yang 
diproduksi oleh Syirkah Aqiqah. Selain itu, media sosial juga termasuk ajang mengiklankan produk, sosial media memang terkenal cepat dalam menyebarluaskan informasi apapun.

Usaha yang dilakukan dalam memasarkan produk memang tidak selalu berjalan mulus. Semua pasti mendapati kesulitan-kesulitan yang datang atau menghambat proses pemasaran yang sedang dijalankan. Hambatan bisa terjadi jika tidak dilakukan dengan strategi-strategi yang bagus

\section{Simpulan}

Berdasarkan hasil penelitian dengan judul strategi komunikasi pemasaran Di Syirkah Aqiqah Surabaya di melalui observasi dan wawancara mendalam, maka dapat ditarik kesimpulan bahwa :

Hasil penelitian ini menunjukkan bahwa strategi komunikasi pemasaran yang diterapkan Syirkah Aqiqah menggunakan bauran pemasaran iklan (advertising), promosi penjualan (sales promotion), penjualan personal (personal selling), pemasaran langsung (direct marketing), hubungan masyarakat (public relation).

Berikut adalah temuan-temuan yang peneliti dapatkan dalam melakukan penelitian saat di lapangan.

1. Word of mouth atau komunikasi dari mulut kemulut merupakan proses komunikasi yang berupa pemberian rekomendasi baik secara individu maupun kelompok terhadap suatu produk atau jasa yang bertujuan untuk memberikan informasi secara personal, word of mouth dapat berupa komentar atau rekomendasi yang disebarkan pelanggan berdasarkan pengalaman yang diterimanya, memiliki pengaruh yang kuat terhadap pengambilan keputusan yang dilakukan pihak lain.

2. Packaging

Kemasan produk dapat menjadi hal yang penting dalam strategi komunikasi pemasaran. Kemasan yang menarik dapat mempengaruhi keputusan konsumen dalam membeli produk. Komunikasi ini bisa dalam bentuk desain, warna serta bentuk dari kemasan produk tersebut.

Syirkah Aqiqah dulu pertama kali menggunakan packaging hanya kotak putih polos biasa, mulai berubah karena kenal orang brand mulai tahun 2014 dan dengan berkembangnya jaman sekarang Syirkah Aqiqah mengeluarkan packaging baru yang lebih menarik

3. Syirkah Aqiqah memberikan diskon dan gratis satu botol Syuniz untuk menarik pelanggan yang merupakan bagian dari promosi penjualan.

4. Pemasaran interaktif atau pemasaran online 


\section{Daftar Pustaka}

Ahmad, Beni Saebani dan Kadar Nurjaman. Manajemen Penelitian. Bandung: CV Pustaka Setia, 2013.

Arifin, Anwar. Strategi Komunikasi Sebuah Pengantar Ringkas. Jakarta: Lembaga Kajian Inovasi Indonesia (LKII), 1982 .

Cangara, Hafied. Perencanaan \& Strategi Komunikasi. Jakarta: Raja Grafindo Parsada, 2013.

Cravens, David W. Pemasaran Strategi, ed. 4. Jilid 2. Jakarta: Erlangga, 1996.

Hermawan, Agus. Komunikasi Pemasaran. Jakarta: Penerbit Erlangga, 2012.

Jefkins, Frank. Public Relation Untuk Bisnis. Jakarta: PT. Pustaka Binaman

Kertajaya, Hermawan. Positioning Diferensi. Jakarta : PT. Gramedia Pustaka Utama. 2005.

Kotler \&Amstrong. Prinsip-Prinsip Pemasaran. Jakarta: Erlangga, 2012.

Kotler, Philip Gary Armstrong. PrinsipPrinsip Pemasaran, ed. 12. Jakarta: Erlangga, 2008.

Kotler, Philip. Manajemen Pemasaran, Analisis, Perencanaan Dan Pengendalian, ed. 5. Jilid 1. Jakarta: Erlangga, 1994.

Maleong, Lexy. J. Metodologi Penelitian Kualitatif. Bandung: Rosda Karya, 2005.

Marzuki. Metode Riset. Yogyakarta: BPFE-UII, 2000.
Morissan. Periklanan Komunikasi Pemasaran Terpadu. Jakarta: Kencana Prenamedia Group, 2010.

Mulyana, Deddy. Metode Penelitian Kualitatif. Bandung: Remaja Rosdakarya, 2004. Presindo, 1987.

Rohim, Syaiful. Teori Komunikasi: Perspektif, Ragam dan Aplikasi. Jakarta: Rineka Cipta, 2009.

Shimp, Terence A. Periklanan Promosi Aspek Tambahan Komunikasi Terpadu, ed. 5. Jilid 1. Jakarta: Erlangga, 2003.

Sistaningrum. Manajemen Promosi Pemasaran. Jakarta: PT Index, 2002.

Sugiyono. Metode Penelitian Kuantitatif, Kualitatif dan $R \& D$. Bandung: Alfabeta, 2009.

Surachman S.A. Dasar Dasar Manajemen Merek Alat Pemasaran Untuk Memenangkan Persaingan. Malang: Bayu Media Publishing, 2008.

Swasta dan Irawan. Manajemen Pemasaran Modern. Yogyakarta: Liberty, 2003.

Tjiptono, Fandy. Strategi Pemasaran, ed. 3. Yogyakarta: Andi, 2008. 